\title{
A nova skyline da Avenida Beira Mar do Rio de Janeiro (1928-1950)
}

\section{Gianne Maria Montedônio Chagastelles ${ }^{1}$}

Introdução

Os arranha-céus no Brasil provêm de um erro profundo. É injustificável e lamentável numa terra rica de espaço esse sistema de construçóes que em outras cidades, em Nova Iorque, por exemplo, tem sua explicação e sua razão de ser. No Rio de Janeiro a existência dos arranha-céus não tem sentido. É uma imitação. As formas de arte não resultam de uma vontade. Não há forma de arte intencional. E, por isso mesmo, os vossos arranha-céus que não correspondem a uma necessidade, que não surgem espontaneamente da terra, são necessariamente uma expressão falsa de arte. Penso muito que, de um modo geral, a arquitetura do Rio é quase uma ofensa à paisagem. Deve-se procurar sempre uma linha correspondente à da natureza.

Luigi Pirandello, 1927 (Apud Barbosa, 1989, p. 98)

1 Doutoranda do Programa de Pós-Graduação em História Social do IH/UFRJ. Bolsista do CNPq. 
Li a entrevista de Pirandello [...] e recordo-me das suas palavras a propósito dos arranha-céus. Se não me engano ele fala na necessidade de se criar no Rio uma arquitetura que se conforme com a linha da paisagem. Tanto melhor. Não seria o caso de se construir edifícios da altura do Pão-de-Açúcar ou do Corcovado? Creio mesmo que embora se fizessem aqui edifícios duas ou três vezes maiores que os de Nova Iorque a linha da paisagem nada sofreria. A própria natureza dá o exemplo a seguir. Demais, em toda cidade em crise de crescimento o arranha-céu é a tábua de salvação. Não há hesitar. Isso não se dá só nos Estados Unidos, mas em toda parte, mesmo em Paris. A extensão dos edifícios no sentido vertical resulta naturalmente da elevação constante no preço dos terrenos. [...] Acho que a observação de Pirandello é idiota: com uma paisagem táo grandiosa o Rio permite e exige mesmo que os seus edifícios sejam altos.

Blaise Cendras, 1927 (Apud BARBOSA, 1989, p. 101)

O processo de verticalização da cidade do Rio de Janeiro desencadeou mudanças no cotidiano das pessoas que vivenciaram a construção e o crescimento dos arranha-céus entre os anos 1928 e 1950. Este artigo procura investigar as práticas, complexas, múltiplas, diferenciadas de apropriação dos edifícios, identificando e selecionando os indícios que expressam de forma significativa a imagem dos arranha-céus, de modo a perceber os signos/símbolos culturais do espaço urbano que se configuraram no espaço da cidade, na sua historicidade. Assim, torna-se fundamental investigar esse processo através das representaçóes dos discursos dos usuários que deram conta das transformaçóes da cidade, discutindo as novas formas de moradia e controle do espaço natural e urbano decorrentes da instauração dessa arquitetura vertical. Nesse processo de ocupação da cidade, formamos e transformamos os territórios em que vivemos, expressando a união entre o substrato material da vida e a atividade humana de produção dos meios de existência que, segundo Milton Santos (1999, p. 86), juntas, constituem a forma-conteúdo reveladora de modos de vida que é a cidade. Por meio desse vínculo, alteramos a geografia natural, produzindo e reproduzindo os ambientes que resultam de nossa apropriação do espaço no tempo, transformando-os em uma segunda natureza. Assim, o espaço é a síntese, sempre provisória, entre o conteúdo social e as formas espaciais (Santos, 1999, p. 86). 
A velocidade das transformações culturais e territoriais na Beira Mar do Rio de Janeiro, se, por um lado, aumentava subitamente a capacidade humana de transformação da natureza, por outro, multiplicava as funções da cidade. Surgia uma nova forma de arquitetura e de moradia, os arranha-céus, assim como, também, um novo modo de vida e uma nova cidade, que resultou das próprias transformaçôes dos propósitos humanos diante das experiências da modernidade. O homem moderno do início do século XX tornava-se, cada vez mais, um ser humano móvel; essa mobilidade refletiu-se no meio físico da cidade, acarretando a formação de novas unidades territoriais, bem como a ocupação de áreas ociosas. Para Leonardo Benévolo (2005, p. 552), a velocidade das transformaçóes que se desenvolveram em poucos decênios no início do século XX não levaram a um novo equilíbrio estável, mas deixaram prever outras transformaçôes, cada vez mais profundas e mais rápidas. Por outro lado, Henri Lefebvre (2004, p. 26) ressalta que dois importantes movimentos de transformação territorial atuavam sobre as cidades existentes: um de adensamento e outro de expansão, ou seja, "implosão-explosão" da cidade. Na cidade do Rio de Janeiro, a progressiva multiplicaçáo de funçóes fazia com que a cidade implodisse sobre si mesma e explodisse para além dos limites até entâo atingidos, especialmente na direção vertical e para o mar. Para esse autor, no primeiro movimento opera-se uma enorme concentraçáo de pessoas, de atividades, de riquezas, de coisas e de objetos, de instrumentos, de meios e de pensamento na realidade urbana. Esse movimento foi impulsionado pelas transformaçóes tecnológicas das construçóes, que permitiam maior verticalização e concentração populacional nas áreas centrais. No segundo movimento, ocorre uma imensa explosão, a projeção de fragmentos múltiplos e disjuntos nas periferias, subúrbios e residências secundárias. Esse movimento foi estimulado pelo desenvolvimento dos meios de transporte coletivos e pela implantação das indústrias nos arredores da cidade, onde se situavam as fontes de energia. Essa nova dinâmica urbana teve repercussóes no dia a dia dos usuários das cidades, transformando não só os territórios, como também as relaçôes sociais e a cultura dos indivíduos. Assim, o aumento súbito da capacidade do ser humano de exercer controle sobre a natureza, bem como as mudanças tecnológicas e da consciência dos indivíduos, levaram às grandes transformaçóes sociais. Este estudo dedica-se à investigação da natureza do espaço urbano em sua trajetória temporal na regiáo beira-mar do Rio de Janeiro durante o processo de verticalizaçáo 
desenvolvido na Era Vargas. Baseia-se na delicada relação entre espaço e sociedade na formação da cidade e nos processos de transformação dos territórios urbanos. A data de início do processo de verticalização é 1928, tendo em vista a construção do Edifício A Noite, marco expressivo do começo das construçôes dos arranha-céus no Rio de Janeiro. Esse prédio, considerado o mais importante arranha-céu da cidade, tanto pela técnica quanto pelo tamanho, foi construído em 1928 e inaugurado em torno de 1930. Por volta de 1950, as construçóes dos arranha-céus monolíticos de concreto armado caem em desuso, e o cânone da arquitetura moderna de edifícios mais baixos, de vidro e ferro, torna-se o grande modelo regulador da arquitetura carioca. Esse cânone moderno teve como grande referência o Edifício Palácio Gustavo Capanema (MES - Ministério da Educação e Saúde), inaugurado em 1943, e que se tornou um modelo paradigmático da arquitetura moderna baseada na concepção purista do funcionalismo ${ }^{1}$ de Le Corbusier. Assim, durante a década de 1940, esses tipos de construção arquitetônica predominaram no espaço da cidade. Finalmente, a partir de 1950, abandonou-se o modo construtivo mediante blocos de concreto armado.

$\mathrm{O}$ acelerado processo de verticalizaçáo do Rio de Janeiro nessa época teve como mola propulsora o Plano Agache (1928-1930), um projeto de remodelaçáo do centro da cidade encomendado pelo prefeito Antônio Prado Júnior. No final da República Velha, o desenvolvimento dos setores secundário e terciário da economia, aliado ao processo de industrializaçáo, suscitou novos contornos urbanos. A fim de abrir o acesso para mercadorias e serviços, iniciaram-se as grandes obras públicas. A prefeitura, visando moldar o crescimento urbano aos interesses do Estado, encomendou o Plano, elaborado por um grupo de técnicos e urbanistas estrangeiros chefiados por Alfred Agache (Reis, 1977, p. 90). O urbanista francês elaborou um programa de "remodelação" da cidade em que propôs um zoneamento ${ }^{22} \mathrm{e}$, especialmente, a verticalização do espaço. Esse plano considerava o problema do crescimento demográfico e da expan-

1 O funcionalismo é uma tendência de caráter racionalista e projetual, segundo a qual as soluçóes para os desenhos de edifícios e sítios urbanos devem atender a consideraçôes práticas, tais como a lógica estrutural, o interesse social, a economia de meios e a obediência estrita à função.

2 O zoneamento é a definiçấo de uso e ocupação do solo através da distinção da cidade por zonas de uso, que podem ser: residenciais, comerciais, industriais, turísticas, institucionais ou agrícolas. Para cada zona, são previstos controles de densidade demográfica, de limites de construção e de intensidade de usos. 
são urbana, tentando satisfazer às demandas da populaçáo. Por outro lado, o plano pensava a cidade como arquitetura, ou seja, os edifícios eram matrizes para a conformação dos espaços públicos. A Revolução de 1930 frustrou a implantação total do Plano Agache, sendo que somente algumas de suas proposiçôes foram concretizadas, particularmente os novos quarteiróes erguidos na Esplanada do Castelo. A partir desse Plano, foi elaborado o Código de Obras da Cidade ${ }^{33}$, de 1937. Portanto, o modelo de desenvolvimento da Era Vargas, a partir dos anos 1930 e 1940, pode ser caracterizado pelo desenvolvimento urbano-industrial, pelo nacionalismo populista e pelo intervencionismo estatal na economia e no social. A intervenção direta do Estado sobre a forma urbana levou à transformação acelerada da paisagem da cidade.

Surgiram, nos anos 1930, grupos consumidores de população de renda média para os quais as empresas imobiliárias criaram espaços modernos e funcionais que se expressaram na Beira Mar. Capitalizando o "status" que a ideologia do "morar à beira-mar" oferecia a quem ali residia, a especulação imobiliária valorizou o solo, substituindo as unidades unifamiliares por arranha-céus multifamiliares, muitas vezes com funçóes mistas de uso, como: residências, cinema, cassino, teatro e comércio. A cidade começou a adquirir um ar monumental e congestionado, que passou a ser chamado de "ar moderno", com os seus arranha-céus de concreto armado.

O traçado ordenado na Avenida Beira Mar, que dá forma geometrizada ao mar, e os arranha-céus monolíticos que a acompanham procuraram exercer um controle e um domínio sobre as pessoas e a natureza. Para este artigo, o espaço urbano deve ser compreendido tanto na sua dimensão físico-ambiental e econômica quanto nos processos da vida social, que repercutem na sua dimensão simbólica. A sociedade relaciona-se com seu espaço material através de um permanente processo de valorização, criando e transferindo os valores produzidos. No Rio de Janeiro, os reflexos do sistema capitalista sobre o comportamento da cidade refletiram os resultados de uma nova lógica valorativa do espaço.

Assim, ainda que Pereira Passos, na primeira década do século XX, tenha destruído "impiedosamente" grande parte da cidade e segregado a popula-

3 Segundo Lucia Lippi de Oliveira, o Plano Agache serviu de orientação para todos os projetos urbanísticos até 1967, quando este foi substituído por um novo plano para a cidade, o Doxíadis (gestão Carlos Lacerda). Cf. (OLIVEIRA, 2002, p. 162). 
ção, é dele o mérito de ter colocado o espaço urbano do Rio de Janeiro e sua historicidade em evidência. O espaço era o grande ausente. Somente a partir do momento em que ele se torna um obstáculo e precisa ser destruído é que ganha a adequada importância. Desenvolveu-se a experiência de articular a dupla operação de construção-destruição na qual residiu a possibilidade de a cidade crescer, já que uma cidade que se constrói é, ao mesmo tempo, uma cidade que se destrói. É no espaço urbano que melhor se podem depreender as diversidades e desigualdades, os impasses e possibilidades da sociedade capitalista contemporânea, pois a grande cidade é uma síntese da sociedade. Palco polifônico por excelência das relaçóes sociais, a cidade se apresenta como topos privilegiado onde ressoam todas as formas de sociabilidade e interação dos sujeitos contemporâneos.

O planejamento da cidade no Rio de Janeiro contou tanto com a tradição europeia proveniente de Haussmann ${ }^{4}$ e o paradigma da circulaçáo quanto com o modelo de planejamento americano, especialmente o de Nova Iorque: o manhatanismo. Em relação a esse último modelo de planejamento, a conformação do espaço urbano passou a se dar a partir da medida modular oferecida pelo quarteiráo, ou seja, por uma retícula. ${ }^{5}$ Aberto em todos os sentidos e com vias desenhadas de modo a sugerir uma possível continuação indefinida na direção dos campos circunvizinhos, o espaço citadino passou a ser delimitado por linhas geométricas que se estendiam até os confins naturais de seu entorno. Aplicava-se em escala até então inédita a malha uniforme de ordenamento do espaço da cidade.

Em relação ao urbanismo, os anos 1928-1950 foram de intensa produção de edifícios na cidade. Esse período não foi só de inovação urbanística no solo, mas principalmente de um rápido preenchimento das malhas já disponíveis desde as reformas urbanas de Pereira Passos no início do século XX. Sobre tais malhas, sucederam-se, intercalaram-se, misturaram-se, sobrepuseram-se, substituíram-se sucessivos tipos e escalas de edifícios. Cada arranha-céu passou a competir com o do lado na quadra, formando um

4 Georges-Eugène Haussmann foi prefeito de Paris durante o Segundo Império, responsável pelas reformas que destruíram a cidade medieval, abrindo-a à circulação mediante estradas de ferro, parques e bulevares. A Reforma de Haussmann é paradigmática na constituição da cidade moderna ocidental.

5 Retícula é o tipo de planejamento urbanístico que disciplina o traçado da cidade. Nesse caso, a retícula é traçada em forma de tabuleiro de xadrez, organizando a cidade em quadras homogêneas e equidistantes, mediante o traçado de suas ruas retilíneas e largas que se cruzam em ângulo reto. 
espetáculo de atrações. Operou-se uma proliferação caótica em um padrão muito rígido e ordenado. O plano disciplinador, a grelha ou a retícula, fascinou pela sua dupla contradição entre a austeridade formal, ou seja, a rigidez geométrica, e a diversidade que paradoxalmente permitiu o ruído a partir da ordem. Nesse sentido, o plano regulador canalizou, guiou e, muitas vezes, acelerou a propulsão de forças que agiam ou estavam por agir na cidade nessa época. Logo, a viabilidade desse conjunto urbano é propiciada pela malha de quadras que permitiu a sua síntese e, dentro desse conjunto, a autonomia dos bairros e dos núcleos residenciais, transformando as quadras em grandes blocos construídos. Assim, aceitando o princípio geral da malha retangular, o plano regulador acabava prestando-se magnificamente aos desígnios da especulação e do pragmatismo.

Na Era Vargas, operou-se a relação da construção de arranha-céus com o otimismo dos novos tempos, que se identificaram com a era da máquina e com os novos programas arquitetônicos da cidade moderna. Essa ideia de modernidade, pautada na era da máquina, difundiu-se por todas as instâncias artísticas inspirada nas formas aerodinâmicas e náuticas. Esses arranha-céus continham linhas e volumes em projeçóes futuristas, que, segundo Nicolau Sevcenko (1992), prenunciavam um mundo em que a vitória total da técnica suprimiria em definitivo as ameaças de contaminação e degenerescência. O homem urbano dessa época estava no centro de uma "espiral de forças" que tudo envolvia em todos os sentidos, culminando na verticalidade do arranha-céu. A imagem do futuro seria expressa na cidade da multidão, da vida coletiva, da metrópole, da velocidade, das comunicaçóes rápidas, das novas experiências psicológicas e perceptivas que o carioca começava a viver. Portanto, expressou-se uma época em que a vida incorporava o ritmo vertiginoso das máquinas e a velocidade dos meios de comunicação e transporte. O horizonte da cidade expandiu-se de forma comparável ao modo pelo qual a riqueza se desenvolvia na cidade naquele momento.

O progresso técnico tornou possível a construção de altos edifícios e, consequentemente, o crescimento vertical. As quadras foram preenchidas pelos arranha-céus dentro de uma competição que levou à congestão da cidade. Os edifícios altos que surgiam em Nova Iorque tinham garantida sua verticalidade pelo esqueleto de aço, porém, apesar de terem servido de modelo arquitetônico para o Rio de Janeiro, os arranha-céus cariocas foram construídos em concreto armado. A importação do modelo do manhatanismo com o preenchimento 
da retícula pelos arranha-céus na cidade do Rio de Janeiro foi polêmica naquela época. Em relação ao processo de verticalização da cidade, por um lado, havia os discursos celebrativos, como, por exemplo, o de Cendras, conforme a segunda epígrafe deste texto, e por outro, havia os discursos de resistência a esse processo de congestionamento da cidade, como, por exemplo, o de Pirandello, conforme a primeira epígrafe. Esse autor contesta a construção de arranha-céus em uma cidade como o Rio de Janeiro, que possuía espaço para crescer horizontalmente sem a necessidade de empilhar apartamentos, atrapalhando a brisa da natureza e a skyline da paisagem entre o mar e a montanha.

Assim, essa problemática que norteia as minhas indagaçôes acerca do processo de reformulaçáo urbana da cidade está relacionada à possibilidade de se falar em uma paisagem vertical no Rio de Janeiro. Ao resgatar os discursos sobre o arranha-céu e as transformaçôes da paisagem da cidade, possibilita-se a construçáo de representaçóes e significaçóes que o espaço da cidade contém. Acredito, ainda, que mediante seleção e interpretação dessas representaçóes sobre a verticalização da paisagem do Rio de Janeiro seja possível mapear possibilidades de reconhecer a cidade em seus múltiplos e dinâmicos significados históricos.

Este texto propóe a inclusão das fontes orais como corpus do trabalho, e estrutura-se a partir das percepçóes individuais dos entrevistados sobre os arranha-céus e suas relaçôes com a cidade. Marieta de Moraes Ferreira (Ferreira e Amado, 2006) afirma que essas percepçóes e lembranças são legitimadas como indícios, seja pelo valor informativo ou pelo valor simbólico, incorporando elementos e perspectivas ausentes em outras práticas históricas, como a subjetividade e as diferentes apropriaçóes do cotidiano. Na história oral, o objeto de estudo do historiador é reconstituído através da atualização das lembranças dos entrevistados; assim, os desdobramentos teóricos que apoiam este estudo levam em consideração a relação entre história e memória, cuja dinâmica sustenta as identidades individuais e coletivas. $\mathrm{O}$ ato de lembrar pressupóe possibilidades múltiplas de elaboração das representações e de reafirmação das identidades construídas na dinâmica da história.

Para Roger Chartier, a noção de apropriação é fundamental para se pensar a cultura e a vida cotidiana dos habitantes da cidade. Segundo esse autor, "a aceitaçáo das mensagens e dos modelos opera-se sempre através de ordenamentos, de desvios, de reempregos singulares" (Chartier, 1990, p. 136-137). A utilização da teoria produzida por esse historiador prioriza as práticas culturais 
sem desconsiderar os processos políticos, econômicos e sociais que atuam junto a essas práticas. Dessa forma, pode-se pensar que os discursos daqueles que moraram ou passaram pelos arranha-céus e vivenciaram seu aparecimento na paisagem urbana e seus rebatimentos na vida citadina trazem em seu conteúdo a indicação de representaçóes da realidade. Essas representaçóes demonstram hábitos mentais, posicionamentos ideológicos, éticos e morais resultantes de condiçôes de interaçôes e imposições, resistências e incorporações, destacando dessa maneira a atenção para as "forças criadoras de hábitos" inerentes a cada grupo em uma mesma época. Nesse sentido, os discursos são considerados dispositivos historicamente localizáveis e não temas ou ideias, portanto, o foco da análise nesta pesquisa se deu no como se relacionam em vez de oquê significam isoladamente. Destarte, as "visóes de mundo" que podem ser inventariadas levam-nos ao contato com demonstraçôes de identidades morais, variáveis cultural e historicamente, compartilhadas e afirmadas por indivíduos de um grupo e de uma geração. Pode-se pensar ainda que, além de compartilharem visões de mundo, as pessoas de uma mesma época em uma mesma sociedade vivenciam experiências individuais, o que nos coloca em posição de dizer que, apesar dos pontos de convergência em aspectos sociais e culturais, há formas particulares de usos dos signos tidos como comuns (Chartier, 1990).

No que diz respeito à reflexão entre história e memória, segundo Paul Ricoeur (2008), essa relação deve ser tratada diferenciando-se essas duas dimensóes, para poder melhor pensá-las em conjunto. Ele lembra que o historiador náo pode se limitar ao estabelecimento dos fatos, pois fazer história consiste em construir, fabricar e criar. A verdade histórica é sempre passível de revisão, em funçáo de novos arquivos e de novas questóes. A reconstrução total do passado é impossível. Logo, somente podemos ter conhecimento do passado mediante relatos orais, escritos e visuais. Para Ricoeur (2008), história e memória operam uma dinâmica solidária e não concorrente. A história se enriquece sob o estímulo das memórias plurais, suporte esse que a configura a todo instante. O presente atualiza o passado a partir de um horizonte histórico separado dele. Transforma a distância temporal morta em transmissão geradora de sentido, pois para Ricoeur (2010), contar já é explicar.

Em relaçáo aos procedimentos metodológicos da pesquisa, trabalhei com três tipologias de fontes: iconográficas, orais e escritas. O intuito foi valorizar o poder de "conversa", contatos ou diálogos entre elas, desenvolvendo a análise do objeto por suas várias dimensôes. $\mathrm{O}$ uso dessa multiplicidade de 
fontes permite ao historiador social um melhor entendimento do seu objeto, devido a uma maior densidade das camadas de significação. Assim, o pesquisador pode mergulhar no universo subjetivo da época, reconstituindo, ainda que de forma parcial, a história das pessoas que presenciaram a construção dos arranha-céus e neles moraram, viveram ou trabalharam.

Em relação à análise iconográfica, utilizei como fontes documentais para a pesquisa as fotografias. A fotografia deve ser valorizada porque fornece, acima de tudo, informaçóes. Dá conta do que existiu e forma um inventário. É importante que se diga que não só em termos de história da arte, mas em geral, a fotografia tem sido um recurso bastante usado pelos historiadores contemporâneos. As fotografias não devem constituir objetos de investigação em si, mas vetores para a investigação de aspectos relevantes no que se refere à organização, ao funcionamento e à transformação de uma sociedade. Trabalhei com imagens de fotógrafos da época ligadas à arquitetura e ao urbanismo da cidade do Rio de Janeiro, coletadas em arquivos. Trata-se de lugares, monumentos, eventos, arquiteturas e fatos da cidade que são marcos importantes do período. Os fotógrafos tinham como objetivo principal, quase sempre, fornecer imagens para os veículos de mídia. Entre eles, Augusto Malta destaca-se por ter trabalhado para a prefeitura, deixando o maior acervo de fotografias da época, como os registros de obras, eventos públicos e transformaçóes do Rio de Janeiro. Assim, a visão que temos atualmente da cidade é inseparável dessas fotografias produzidas por eles.

Destarte, neste estudo, desenvolvi o poder de conversa entre os indícios visual e oral. Em relação à história oral, as entrevistas ajudaram a constituir um quadro das representaçóes dos arranha-céus no processo de verticalização do Rio de Janeiro. O conjunto das entrevistas ganha força com suas imbricaçóes e inter-relaçóes. A seleção dos entrevistados considerou que eles vivenciaram a verticalização da cidade do Rio de Janeiro na época da construção dos primeiros arranha-céus. A partir disso, iniciei a procura de pessoas de idade avançada dispostas a compartilhar suas lembranças para esta pesquisa. $\mathrm{O}$ roteiro de entrevista foi elaborado a partir do percurso que vai desde o olhar subjetivo e amplo de cada um dos entrevistados sobre o Rio de Janeiro até as formas de sociabilidade que foram estimuladas com o aparecimento dos arranha-céus na cidade.

Para este artigo, vou apresentar os depoimentos de três pessoas que viveram na cidade do Rio de Janeiro e assistiram à verticalização e às transfor- 
maçóes da cidade. Os entrevistados selecionados moravam na zona sul e no centro da cidade, onde foram construídos os primeiros arranha-céus. Neste estudo, levei em consideração as condiçôes de produção das lembranças dos entrevistados, ou seja, quem fala, de onde fala, como fala, quando fala e para quem fala. Assim, fiz uma pequena biografia de apresentação de cada um dos entrevistados para localizá-los socialmente na época, dando atenção às suas trajetórias de vida.

\section{Os entrevistados}

O senhor Renato Eloy Morgado nasceu no interior do estado de Sáo Paulo, em 1925, e por causa da morte de sua mãe resolveu migrar para o Rio de Janeiro. Desde a juventude no interior de Sáo Paulo, o senhor Morgado sonhava com a cidade e suas praias. Ele se lembrou da Revoluçáo de 1930, sobretudo pelos sacrifícios econômicos que algumas cidades e os seus citadinos passaram. Antes da sua chegada ao Rio de Janeiro, em 1948, o senhor Morgado tinha feito as primeiras incursóes no mundo da fotografia, fundamentais para seu desenvolvimento profissional como repórter fotográfico na capital. Ele é repórter fotográfico desde sua juventude no Rio de Janeiro, tendo trabalhado para agências internacionais, como Associated Press e United Press. Nos anos seguintes à sua chegada, continuou trabalhando como repórter fotográfico, e depois que se casou mudou-se para Copacabana e, em seguida, para uma casa na Tijuca, onde vive até hoje com a sua mulher e seus filhos.

O senhor Osório Guimarães Resende é proveniente de uma família numerosa da Bahia, que pouco a pouco se dispersou. A vida de infância que o senhor Resende descreve é do tipo rural, com as atividades próprias da cotidianidade de uma roça, com todas as culturas para a subsistência familiar. Devido a essa situação, o senhor Resende saiu da chácara aos 14 anos. Em relaçáo ao contexto político, descreve o panorama da época revelando sua visão em relação à disputa dos partidos Comunista e Integralista, que terminou no Golpe do Presidente Getúlio Vargas em 1937, com a instauração do Estado Novo no Brasil. Quando o senhor Resende chegou ao Rio de Janeiro, em 1945, instalou-se na Praça Tiradentes, na 
pensão de uma portuguesa, e depois na pensão de uma espanhola. Por fim, foi morar em um quarto alugado na Rua Monte Alegre, em Santa Teresa, sempre compartilhando com mais uma ou duas pessoas. Iniciou a vida no Rio trabalhando em uma padaria na Rua da Carioca, 81, que fornecia os pães para as pensóes da vizinhança. Em 1948, o senhor Resende serviu ao Exército, na Escola de Sargento das Armas, abandonando-a depois para trabalhar na Confeitaria Colombo de Copacabana, onde permaneceu até 1950. Após o trabalho na Confeitaria Colombo, trabalhou, entre outros empregos, na loja de sapato Polar, onde permaneceu por muito tempo. Hoje ele está aposentado e vive com sua terceira esposa na Lapa, no centro do Rio de Janeiro.

A senhora Luz Helena de Peyon Wright nasceu no Rio de Janeiro, em uma casa de chácara no bairro da Gávea, em 1926, onde ficou até os quatro ou cinco anos, quando se mudou para uma casa na Avenida Pasteur, em Botafogo, perto da Clínica de Botafogo. Uma das primeiras e mais intensas lembranças de sua infância é a de ter visto os soldados da Revolução de 1930 sentados em frente à sua casa com suas baionetas erguidas. Foi um momento de cerco para o bairro, disse a senhora Wright: "A gente não podia nem abrir a porta. Às vezes faltava comida e não podia sair para comprar comida. Mas, tinha muita comida naquele tempo... Acho que eu estava com quatro anos... Marcou! Eu me lembro dos soldados sentados com a baioneta, porque a gente olhava pela janela." (Depoimento da senhora Wright).

Assim, foi dentro desse clima tenso na cidade que a senhora Wright vivenciou a presença dos militares em frente à sua casa em Botafogo. Depois de viver na Avenida Pasteur, ela e sua família foram para uma casa construída pelo seu tio na Rua Saint Roman, em uma ladeira perto da Rua Sá Ferreira, em Copacabana, quando tinha entre seis ou sete anos. A senhora Wright e sua família permaneceram na Rua Saint Roman durante dois anos, depois passando a residir em uma casa alugada na Rua Pompeu Loureiro, ainda em Copacabana, pois sua avó ficou doente na casa da Rua Saint Roman devido ao vento encanado que vinha do mar. Entre 1943 e 1944, sua família mudou-se finalmente para um apartamento no primeiro andar de um edifício na Rua Constante Ramos, 56. Esse prédio, assim como os poucos que havia na época, já era considerado um arranha-céu, apesar de ter 12 andares. A senhora Wright alternava seus dias entre os 
banhos de mar na praia de Copacabana, os passeios nas ruas do bairro e a vida cotidiana no apartamento em que vivia com sua família sob os cuidados do seu tio. Ela viveu na casa do seu tio até se casar, em 1948, com um oficial norte-americano. Depois de casada, foi morar nos Estados Unidos por dez anos, mas vinha frequentemente visitar sua família. Quando retornou definitivamente para o Rio de Janeiro, mais especificamente para Copacabana, a senhora Wright começou a trabalhar como secretária da presidência de uma firma americana. Quando se aposentou nessa firma, tornou-se professora de inglês, e até hoje vive em um arranha-céu no bairro de Copacabana, próximo à Rua Constante Ramos, onde morava antes de se casar.

A origem dos entrevistados é variada, sendo a senhora Wright uma "carioca da gema", e os outros dois migrantes do interior do país. Ela foi criada na zona sul, o que se reflete na circunscrição geográfica das suas lembranças, remetidas sempre aos bairros da sua juventude. Assim, a senhora Wright pertence a uma elite endinheirada proveniente da oligarquia da borracha, com uma educação característica da belle époque, como, por exemplo, aulas particulares de piano e francês e visitas a propriedades e sítios à procura de lazer e descanso. Igualmente, os homens da sua família, dentro dessa lógica da República Velha, deveriam ser educados na França. Por outro lado, o senhor Morgado e o senhor Resende, que chegaram ao Rio de Janeiro provenientes do interior do país, tiveram uma infância mais rural, e seus contatos com a cidade grande ocorreram ainda na juventude. O Rio de Janeiro parecia estar na imaginaçáo deles como símbolo de progresso pessoal e de oportunidades de vida, de riqueza e de lazer, decorrentes da movimentação própria de uma grande capital. Ainda assim, suas motivaçôes para vir à cidade foram diversas. O senhor Resende, cuja família se fragmentou cedo, dispersando-se pelo Brasil, chegou ao Rio de Janeiro fugindo da pobreza. Devido a essa vivência alternativa e flutuante, tornou-se uma pessoa com facilidade para lidar com as mudanças e arriscar o novo. Apesar de o senhor Morgado também ser órfão de mãe, teve uma criação mais estável, pelo menos financeiramente. A sua chegada ao Rio de Janeiro foi acompanhada de uma vontade de crescimento profissional específico, isto é, de tornar-se jornalista fotográfico. Assim, ele era envolvido com um campo profissional muito relacionado com os meios de comunicaçáo de massa: o jornal. Essa mídia foi alavancada com o crescimento da indústria 
cultural da época, ao lado do rádio, do cinema e das revistas ilustradas. Esses meios de comunicação eram símbolos da cidade cosmopolita e moderna, assim como os arranha-céus, que imprimiram uma marca no crescimento da cidade. A imagem dos primeiros e mais marcantes arranha-céus é lembrada pelos entrevistados. Para todos eles, o Edifício A Noite foi o grande marco do surgimento dos arranha-céus na cidade. O senhor Resende diz que esse edifício era insuperável, o mais alto e esplêndido de todos os arranha-céus: "E tinha o maior edifício do Rio de Janeiro, que era o edifício A Noite, da Rádio Nacional, na Praça Mauá. Fora isso não tem. Aí foi surgindo um prédio, foi surgindo outro" (Depoimento do senhor Resende). Já o senhor Morgado lembra-se do primeiro edifício em que viveu, localizado na Avenida Beira Mar. Tanto o senhor Morgado quanto a senhora Wright lembram-se dessa avenida e das suas transformaçóes nesse período, como seu aterro e sua acelerada verticalização.

\section{A Avenida Beira Mar}

A Praça Paris, perto da Cinelândia, destaca-se pela quantidade de arranha-céus à sua volta. Essa praça foi construída no governo de Prado Junior, durante a presidência de Washington Luiz, sendo concebida originalmente por Alfred Agache. Como projeto de embelezamento, os jardins da praça eram executados e cuidados pelos imigrantes italianos que moravam nas vilas do centro da cidade. Destacavam-se em volta da praça os edifícios Serrador e Brasília, a torre do relógio da Mesbla, assim como o já derrubado Palácio Monroe.

O senhor Morgado morou em frente à Praça Paris, no limite entre o centro e o bairro da Glória. Ele descreve como era o primeiro prédio onde viveu:

Era um edifício construído pelo Ministério da Guerra para oficiais do exército. E a dona desse décimo andar alugava. Ela ficou viúva e então alugava uma parte do apartamento, porque ali era muito grande, mesmo dividido tinha mais dois quartos, banheiro, cozinha, a sala bem grande. (Depoimento do senhor Morgado) 


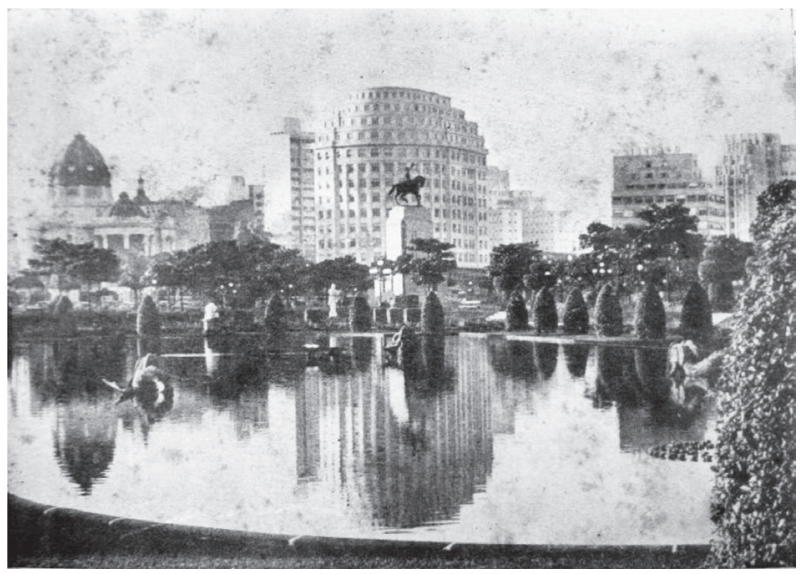

Fig. 1. Praça Paris, Rio de Janeiro (REVISTA DE ARQUITETURA, 1941).

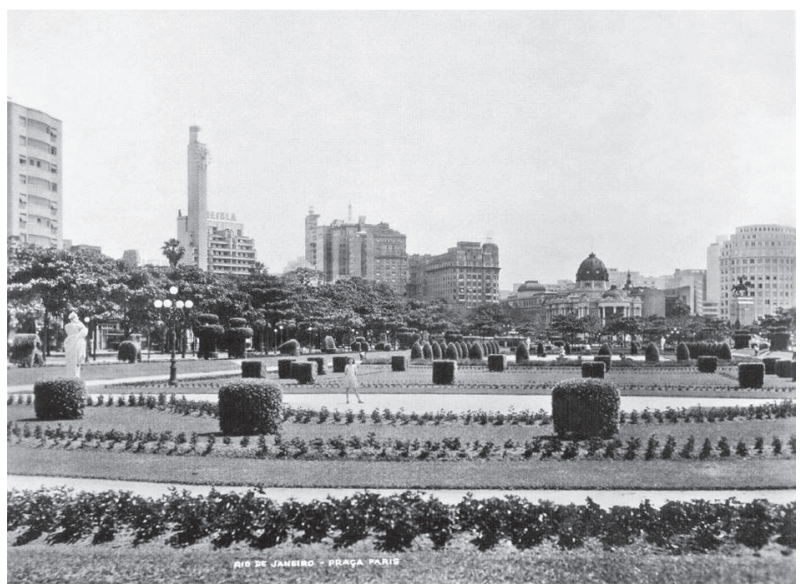

Fig. 2. Praça Paris, Rio de Janeiro, 1950. Coleção G. Ermakoff. O primeiro edifício do lado esquerdo da fotografia foi a residência do senhor Morgado.

A Praça Paris foi planejada inspirada na concepção francesa de jardins em uma área aterrada com os restos do Morro do Castelo. Essa praça tem uma sequência de arbustos podados, de espécies florais ordenadas geometricamente, além de estátuas e bustos colocados simetricamente no espaço. Nessa área da cidade, onde se cruzavam grandes avenidas, como a Beira Mar e a Rio Branco, localizavam-se outros prédios e casaróes que, mesmo não existindo mais, foram referências para o deslocamento dentro da cidade e, 
portanto, permanecem vivos nas lembranças dos usuários. Nesse sentido, a senhora Wright relata que as famílias abastadas das antigas oligarquias cafeeiras opunham-se, no início, a essas mudanças urbanas, preferindo uma vida mais tranquila e tradicional nos seus grandes casaróes. Essas famílias moravam na Glória, no Catete, no Flamengo e em Botafogo, porém paulatinamente começaram a procurar o prestígio que dava morar nos modernos edifícios de apartamentos:

As famílias mais antigas moravam muito na Glória. Aquelas famílias de nome. E depois, o Flamengo também começou com uns edifícios muito interessantes. Tem um que tem até hoje lá que tem umas guirlandas douradas. Biarritz, acho que é o Biarritz. E tinha um também de esquina já escurão, de pedra, a princípio era todo muito escuro. Também era muito visível e de gente de mais dinheiro [o Edifício Seabra]. E depois, quando abriu aquela passagem entre Botafogo e Flamengo, a Avenida Osvaldo Cruz, ali que tinha umas casas lindas com lagos, de gente riquíssima. Acabou tudo. Tudo virou apartamento. Mas, ali era uma passagem linda. Era tudo de casas lindas de gente muito rica. Nesses grandes edifícios moravam pessoas ricas (Depoimento da senhora Wright).

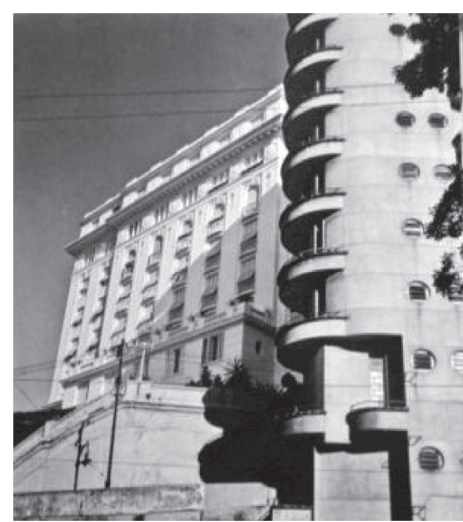

Fig. 3. Fotografia do Hotel Glória com o Edifício Ipú, Rio de Janeiro, 1950, Jean Manszon. CEPAR Consultoria e participações.

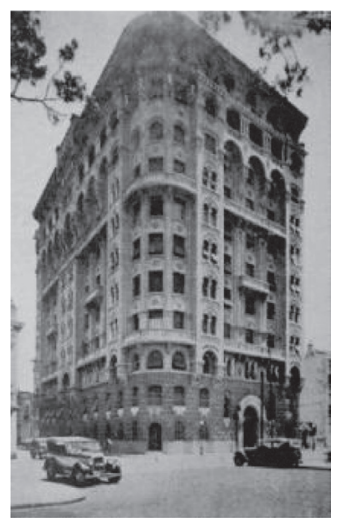

Fig. 4. Fotografia do Edifício Seabra, no Flamengo, Rio de Janeiro. (REVISTA ARQUITETURA E URBANISMO, 1936).

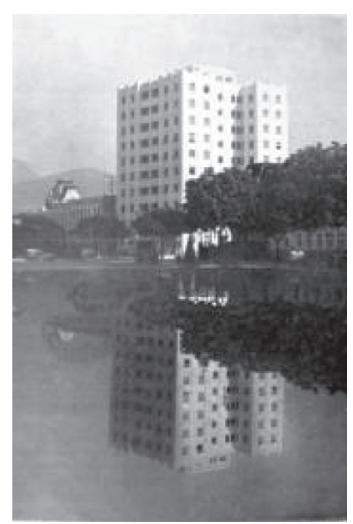

Fig. 5. Fotografia do Edifício Pimentel Duarte, em Botafogo, Rio de Janeiro. (REVISTA ARQUITETURA E URBANISMO, 1936. p. 131). 
Os três marcos da construção em altura na Beira Mar do Rio de Janeiro foram os arranha-céus Ipú, Seabra e Pimentel Duarte (figuras 3, 4 e 5). Na primeira fotografia (Figura 3) aparecem dois prédios, o Hotel Glória e o arranha-céu Ipú, esse último tendo sido realizado por Eri Leon Rey e Floriano Brilhante, e construído em 1935 pela Cia. Imobiliária e Hotelaria Sul do Brasil. $\mathrm{O}$ edifício surpreende pela forma como supera as dificuldades do terreno irregular com sua unidade. De inspiração náutica, evidente nas superfícies planas e na progressão das varandas e saliências, é simplificado e geometrizado com um ritmo de ascensão ao céu. Na fotografia da Figura 4, o Edifício Seabra, no Aterro do Flamengo, foi construído no ano 1931 e projetado por Mario Vodret. Era um ícone de elegância pela utilização da linguagem toscana, contendo quatro elevadores. Finalmente, na fotografia da Figura 5, o Edifício Residencial Pimentel Duarte, construído por Pires \& Santos Construtora, localizado na Praia de Botafogo, tinha um jardim que se destacava na Avenida Beira Mar. O aterro da Baía de Guanabara, em especial das praias do Flamengo e de Botafogo, causou espanto para a senhora Wright. Ela explica como aconteceu:

Ah, o Aterro! Isso eu me lembro, muito bem! Foi horrível! Ah, a gente não achava nada, porque nunca tinha visto aterrar nada. Embora, muita gente foi contra, porque tirava um pedaço da Baía. Diminuiu a Baía. Então muita gente foi contra. Isso eu me lembro. Que foi um debate muito grande. Porque uns diziam que mudavam as correntezas, mudavam... Eu me lembro delas antes. A gente ia à beirada, o ônibus passava na beirada. Era mais bonito, bom, eu achava. Mas, depois que foi feito eu achei bonito também (Depoimento da senhora Wright).

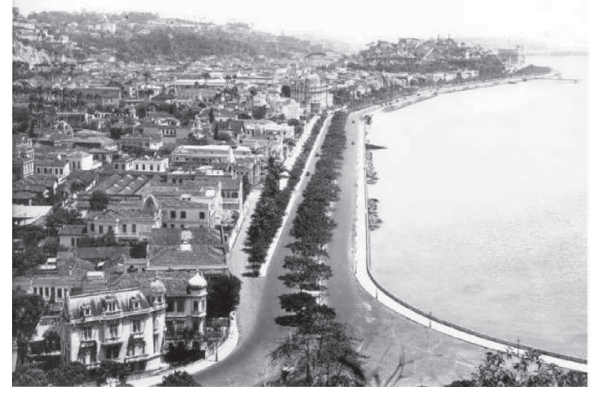

Fig. 6. Fotografia da vista do fim da Praia do Flamengo, na esquina da Rua Oswaldo Cruz, Rio de Janeiro, circa 1920. Acervo da Biblioteca Nacional. 


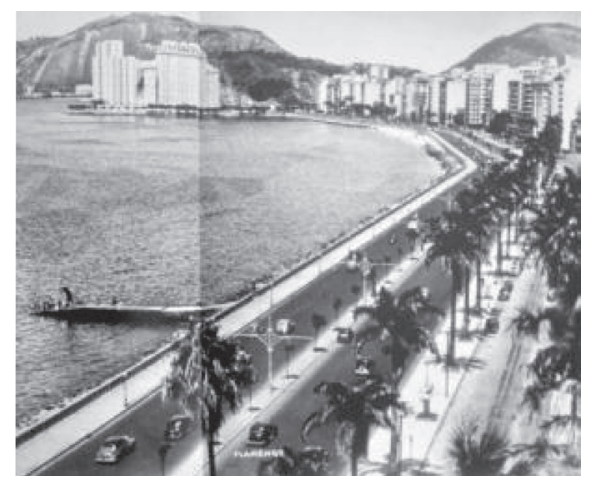

Fig. 7. Fotografia da vista aérea da Praia do Flamengo, Rio de Janeiro, 1950. Coleção G. Ermakoff.

No início do século XX, com Pereira Passos, começava-se a esboçar a forma definitiva dessa regiáo, com a abertura da Avenida Beira Mar assentada sobre o aterro resultante do desmonte do Morro do Senado e de parte do Morro de Santo Antônio. A nova avenida, estendida em 1922 com a abertura da Avenida do Contorno (futura Rui Barbosa), foi projetada para dar acesso mais rápido entre o centro e a zona sul, e para incrementar o valor residencial da regiấo. A partir do Código de Obras de 1937, as alturas do Flamengo, da Glória e do Catete passaram a se erguer sob a legislação com prós e contras. É o caso do Decreto de 1941, que flexibilizou os gabaritos, permitindo a conformação de grandes muralhas de edifícios alinhados, com alturas entre 12 e 17 andares. Nas duas fotografias podemos apreciar o processo de verticalização acentuado nessa região.

Nos dois casos, temos a introdução da vegetação/arborização, mas sempre como conjunto matematicamente implantado, criando aleias regulares sujeitas a um traçado rígido. Mesmo sendo uma via litorânea, na Avenida Beira Mar houve preocupação com a regularização do limite entre a terra e o mar, em trechos retos ou em curvatura geométrica, com pavimentação e calçadão. Para a constituição desse aterro, ignorou-se a vegetação nativa de mangue e restinga, e também se regularizou a textura da orla mediante extração de pedras ou quaisquer elementos “irregulares” à linha d'água. Na orla, os transeuntes podiam ter uma vista magnífica do mar e dos morros, entretanto a construção da Avenida estabeleceu no seu traçado uma retificação que "civilizou" a natureza. O embelezamento desse tipo de renovação acabou por introduzir em suas práticas a natureza projetada, ou seja, o conceito de segunda natureza de Milton Santos (1999). 
Como parte do projeto modernizador, a cidade tornava-se um cenário para o espetáculo da vida cotidiana. Assim, o Rio de Janeiro destacava-se por seu cosmopolitismo, abrigando um urbanismo e uma arquitetura espetaculares, com iluminação típica das grandes metrópoles dos Estados Unidos e da Europa, como Paris e Nova Iorque. A iluminação das praias era importante na época, estendendo-se pela Avenida Beira Mar, que permanecia acesa de noite. Isso permitia desfrutar da cidade à noite, de modo que os usuários podiam caminhar tranquilamente pelas praias de Botafogo e Flamengo. O senhor Morgado descreve as sensaçóes prazerosas dessas caminhadas noturnas:

A iluminação era linda, ali no centro da cidade, na orla do mar, porque era antes do Aterro, e ali no final da Avenida Rio Branco era tudo com poste de ferro, mas todo produzido, desenhado. Eram muito bonitos. Eram verdadeiros lampióes. Tinha poste que levantava com três e quatro lampiōes (Depoimento do senhor Morgado).

A senhora Wright fala também da iluminação do Rio de Janeiro. Ela lembra que os lampiôes, tanto da Avenida Rio Branco, no centro da cidade, quanto da Avenida Atlântica chamavam atenção pela sua beleza e sua forma globular. Diz ela: “Tinham essas luzes assim. Desde pequena eu me lembro dessas luzes. Era lindo até. Acendia tudo e as luzes [dos lampióes] eram lindas, porque era tipo globo" (Depoimento da senhora Wright).

Dentro das transformaçóes da iluminação no meio ambiente da cidade, o senhor Morgado lembra como se destacavam alguns anúncios luminosos encravados na pedra dos morros que davam para a orla do Flamengo e de Botafogo:

São os anúncios luminosos. Eram encravados [na pedra] com ferro, são letreiros de néon. De noite acendiam. Ah! esse aqui, Lisoform. E tinha um d'água que tinha a garrafa escorrendo no copo assim. Fazia aquele efeito com luzes (Depoimento do senhor Morgado).

Por outro lado, em relação à iluminação dos arranha-céus, a senhora Wright afirma que durante a noite todos os edifícios ficavam iluminados: "era tudo iluminado! Era bonito! Era tudo iluminado! O pessoal ficava na varanda, na janela, olhando o movimento. Já tinha bastante movimento" (Depoimento da senhora Wright). 


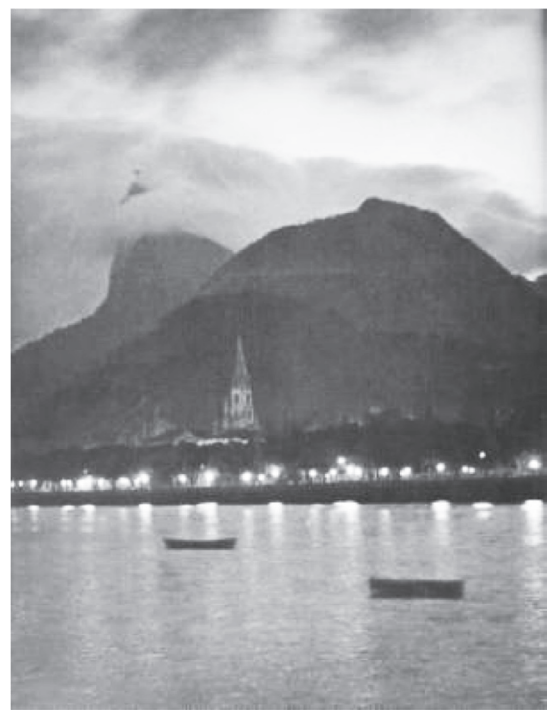

Fig. 8. Fotografia da Avenida Beira Mar, Rio de Janeiro, 1940. G. Jacob. Coleção G. Ermakoff.

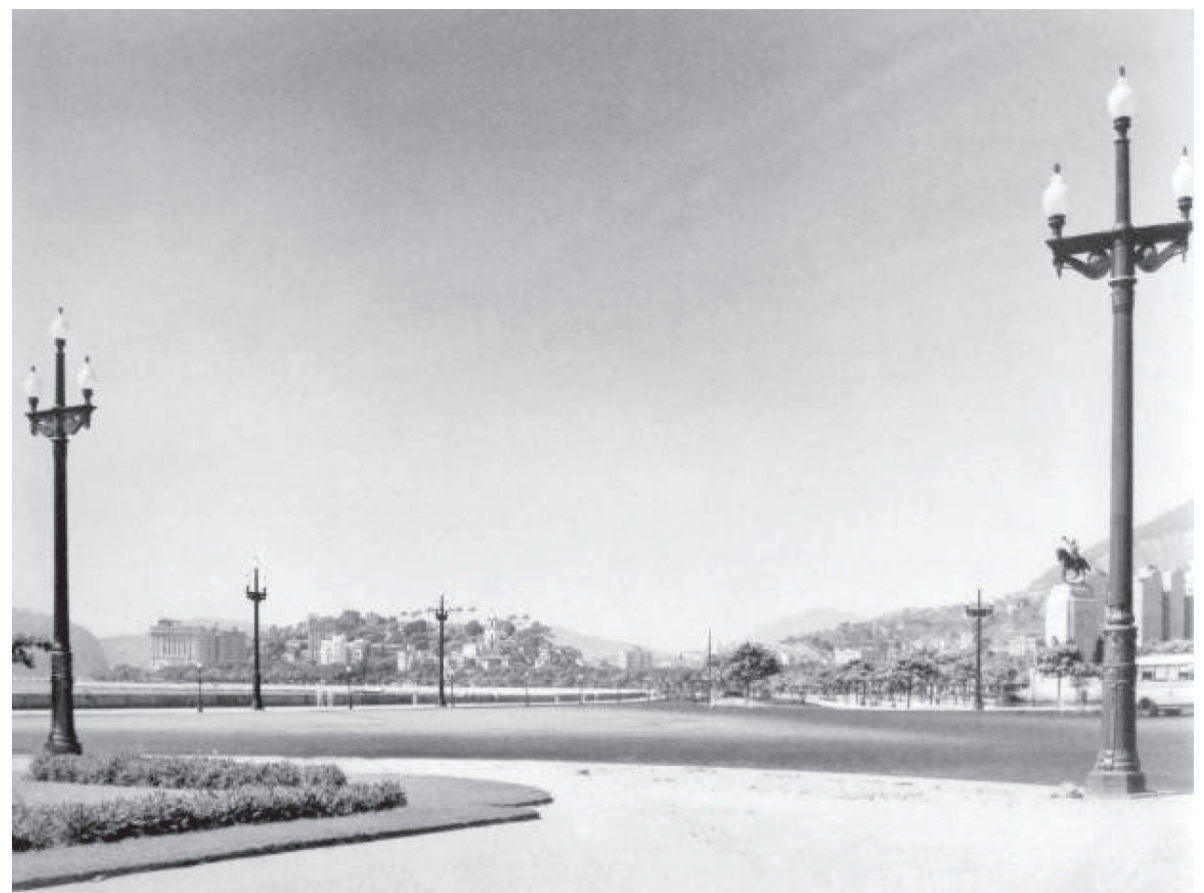

Fig. 9. Fotografia do anoitecer na Avenida Beira Mar, Rio de Janeiro, 1946. José Oiticica Filho. Coleção César e Claudio Oiticica. 


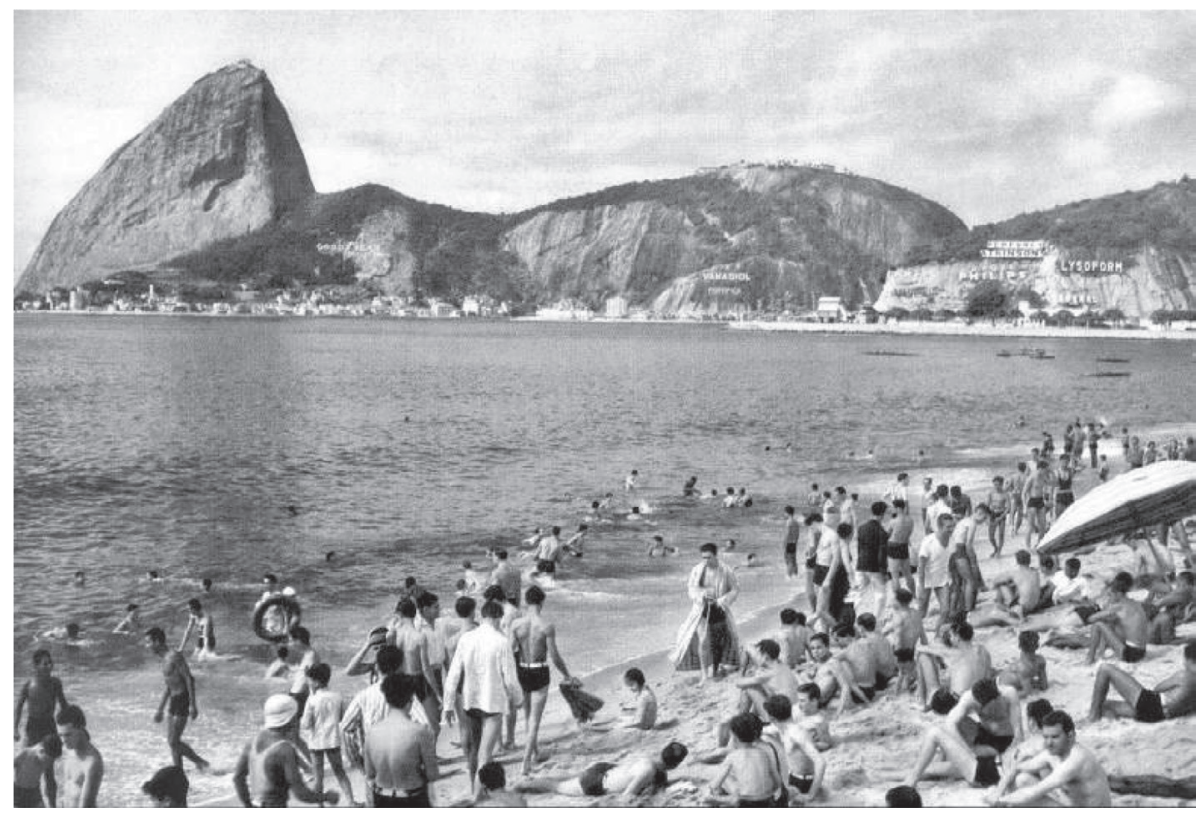

Fig. 10. Fotografia da Praia do Flamengo e do Pão de Açúcar, Rio de Janeiro, 1937. Peter Fuss. Brasil, Atlantis-Verlag. Coleção G. Ermakoff.

Nas três fotografias (figuras 8, 9 e 10), aprecia-se a preocupação em tirar partido da iluminação elétrica como meio de comunicação da arquitetura e do mobiliário urbano, principalmente à noite, quando a Beira Mar fervilhava de transeuntes atraídos pelos anúncios e lampióes luminosos existentes no local. Percebe-se que a arquitetura destinada à noite reflete $\mathrm{o}$ simbolismo da cidade espetáculo. Os postes elétricos iluminavam as noites, estimulando o ir e vir das pessoas na rua. A cidade torna-se elétrica, um "show que não pode acabar", e a arquitetura dos arranha-céus acompanha esse ritmo, valorizando a iluminação noturna e espetacular. Assim, houve um uso cenográfico da luz elétrica espalhando-se para o espaço público, criando campos de destaque visual.

A iluminação tornou-se um elemento arquitetônico representativo da cidade moderna. Essa iluminação da Avenida Beira Mar ressignificou a paisagem, tanto pela inclusão dos morros com os anúncios de neon gigantescos quanto pela possibilidade de se desfrutar da cidade noturna. Isso foi possível pela expansão da infraestrutura da energia elétrica no país, que teve 
um maior impacto na capital, aumentando o movimento das ruas não só durante o dia, como também durante a noite.

A cidade começou a ser planejada para dar resposta à circulação dos automóveis que se intensificava nessa época, de modo que os planejadores deram a prioridade à criação e ao alargamento de ruas e avenidas. Para Tom Gunning (2004), a modernidade náo pode ser entendida fora do contexto da cidade, que proporcionou uma arena para a circulação de corpos e mercadorias, a troca de olhares e o exercício do consumismo. $\mathrm{O}$ ambiente da cidade tornou-se cada vez mais abarrotado, caótico e estimulante, tanto pelo aumento da população urbana como pela intensificação da atividade comercial, a proliferação dos sinais, o acréscimo da densidade do trânsito das ruas e os arranha-céus nas quadras. A cidade passou a ser local de circulação de corpos, mercadorias e automóveis, num exercício de fluxo constante de consumo exacerbado. Ela tornou-se cada vez mais hiperestimulante, hiperlotada, enfim, uma metrópole delirante. Jonathan Crary (2004) afirma que um dos aspectos cruciais da modernidade é uma crise contínua da atenção. $\mathrm{O}$ autor vê as configuraçóes variáveis do capitalismo impulsionando a atenção e a distraçáo a novos limites e limiares, com a introdução ininterrupta de novos produtos, novas fontes de estímulo e fluxos de informaçóes e, em seguida, respondendo com novos métodos de administrar e regular a percepção.

A cidade como "mundo de mundos" devia ser absorvida intensamente e velozmente, não era possível pensar em um descanso. Em estado de vigília constante, cada indivíduo dentro do seu carro andava de lá para cá, procurando uma nova diversão na cidade: cinema, cassino, cabaré... A nova sociedade cujos valores foram se construindo transitava entre os extremos das novas sensaçóes artificiais, materiais e mentais. À vertigem provocada pelos arranha-céus e carros somou-se o artificialismo do consumo na vida cotidiana, a impostura dos edifícios pomposos, os jardins constituídos como uma domesticação da natureza e a inversão da noite pelo dia.

Dessa forma, o preenchimento das quadras pelos arranha-céus fez com que estes multiplicassem o valor do solo devido a seus tamanhos desmesurados, o que impôs novas condiçóes à arquitetura e ao urbanismo, bem como novas possibilidades à congestão da cidade. A ideia de verticalização e congestão expressa a noçáo de modernidade em que a paisagem antiga e natural some em volta dos prédios, ou seja, cria-se uma nova linha da cidade. 
As formas verticais repetem-se em blocos que crescem e se multiplicam caoticamente. Multiplicação do terreno e apropriação carioca do manhattanismo, ou do plano urbanístico de Nova Iorque, que precisa do plano urbanístico da retícula, da disciplina das quadras para se desenvolver, e que tem como único limite o mar e a montanha. Esse limite é contestado sempre mediante a ampliaçáo do solo da cidade para o mar e pela reprodução do solo mediante os arranha-céus. Assim, a cidade progride no sentido desenvolvido por Lefebvre (2004), isto é, em todas as direçôes ilimitadamente.

A cultura da congestão, para Koolhaas (2008), significa a condição essencial da metrópole real, a riqueza genuína da modernidade. $\mathrm{O}$ autor faz uma analogia entre a estrutura urbana, a complexa relaçáo entre o plano disciplinador, os arranha-céus e o capitalismo. A malha regular implica, sobretudo, um programa intelectual que reivindica a superioridade da construção mental sobre o complexo emaranhado da realidade. O plano regulador é celebrado não como uma forma urbana, mas como uma espécie de malha flexível que permite o máximo de controle sobre o máximo de descontrole. Dessa forma, o preenchimento da malha pelos arranha-céus faz com que estes multipliquem o valor do solo devido a seus tamanhos desmesurados, o que impóe novas condiçóes à arquitetura e ao urbanismo, bem como novas possibilidades à cultura da congestão. Opera-se na cidade do Rio de Janeiro um duplo movimento do solo em que a cidade avança horizontalmente além dos seus limites, rompendo as restriçóes impostas pela natureza, ou seja, um duplo movimento tanto em direçáo ao mar quanto em direção ao céu.

Destarte, percebi que os entrevistados concordam em relação ao processo de verticalização, descrevendo-o como vagaroso e paulatino. Diante dessa afirmativa, constatei algumas questóes sobre história e memória que me convidaram ao pensamento e à reflexão. Será que esse discurso dos entrevistados de que o processo de verticalização não causou impacto está ligado ao otimismo com que os usuários absorviam a transformação da cidade e a incorporação dos novos arranha-céus? Ou será que a diferença temporal entre as vivências dos usuários naquela época e a atualização de suas lembranças hoje nas entrevistas, fizeram com que eles quisessem dar uma ordem a suas vidas e ao processo de transformação da cidade?

Os esquecimentos e as lembranças fazem parte de um processo de construçáo individual, de modo que se apresentam e se atualizam com uma 
sensação teleológica. Isso quer dizer que as pessoas organizam suas lembranças para dar uma ordem e uma lógica a suas vidas, e assim aos seus discursos. A fonte oral que estou usando constrói-se no momento preciso da entrevista, diferentemente de outras fontes que foram construídas a partir das práticas daqueles anos. Entretanto, para que se pudesse ter uma mais detalhada reconstituição, mesmo que parcial, do passado foi necessário fazer um diálogo entre as fontes orais construídas hoje e as fotografias da época. O presente trabalho teve como corpus de análise as fontes orais, procurando perceber as modificaçôes da vida social no Rio de Janeiro entre 1928 e 1950. Através dos discursos dos entrevistados, foi possível entender a construção cultural de um novo modo de vida, permeado pelos arranha-céus. Assim, partindo da história oral e das memórias dos entrevistados, privilegiei a cidade como locus e como um objeto passível de ser problematizado a partir do valor simbólico dessas fontes.

Busquei fazer uma contribuição ao esforço reflexivo e interpretativo, que abre um caminho para uma história enriquecida pela reflexão necessária sobre os indícios do passado no presente. A partir dos discursos dos entrevistados, desconstruí a documentação, para dispô-los em ordens coerentes significantes. Modalizei na medida do possível para testar meus instrumentos interpretativos sobre a estruturação das práticas sociais e suas representaçóes do processo de verticalização da cidade do Rio de Janeiro entre 1928 e 1950.

A partir das entrevistas, foi possível identificar visóes pessoais e particulares. Estrutura-se um conjunto de olhares diversos sobre a cidade que varia de acordo com a experiência de cada um. Para a senhora Wright, a cidade do Rio de Janeiro era particularmente circunscrita à zona sul, que apesar de ser uma região nobre da cidade, não teve limitado o seu acesso aos outros entrevistados. Essa abertura cultural e a diversidade social começaram a ser uma característica da cidade do Rio de Janeiro, especialmente da área que crescia à Beira Mar, do centro em direção à zona sul, isto é, o local onde subiram os arranha-céus. Essa região era aberta para pessoas de diferentes origens sociais e culturais que, ao frequentá-la, teciam uma rede de sociabilidade que permitiu um relacionamento muito íntimo entre o centro da cidade e a zona sul. Começava, assim, a abertura do Rio de Janeiro para o mundo. 


\section{Referências}

BARBOSA, Francisco de Assis (Org.). Raizes de Sérgio Buarque de Holanda. Rio de Janeiro: Rocco, 1989.

BENÉVOLO, Leonardo. História da cidade. São Paulo: Perspectiva, 2005.

CHARTIER, Roger. A História Cultural: entre práticas e representaçóes. Lisboa: DIFEL, 1990 .

CRARY, Jonathan. A visão que se desprende: Manet e o observador atento no fim do século XIX. In: CHARNEY, Leo e SCHWARTZ, Vanessa R. (Org.) O cinema e a invenção moderna. São Paulo: Cosac Naify, 2004.

ERMAKOFF, George. Rio de Janeiro de 1900-1930: uma crônica fotográfica, Rio de Janeiro: Casa Editorial, 2003.

Rio de Janeiro de 1930-1960: uma crônica fotográfica, Rio de Janeiro: Casa Editorial, 2008.

FERREIRA, Marieta de Moraes e AMADO, Janaína (Org.). Usos \& abusos da história oral. Rio de Janeiro: FGV, 2006.

GUNNING, Tom. O retrato do corpo humano: a fotografia, os detetives e os primórdios do cinema. In: CHARNEY, Leo e SCHWARTZ, Vanessa R. (Org.). O cinema e a invenção moderna. São Paulo: Cosac Naify, 2004.

KOOLHAAS, Rem. Nova York delirante: um manifesto retroativo para Manhattan. São Paulo: Cosac Naify, 2008.

LEFEBVRE, Henri. A revolução urbana. Belo Horizonte: UFMG, 2004.

OLIVEIRA, Lucia Lippi. Cidade História e Desafios. Rio de Janeiro: FGV, 2002.

REIS, José de Oliveira. O Rio de Janeiro e seus prefeitos: evolução urbanística da cidade. Rio de Janeiro: Prefeitura da Cidade do Rio de Janeiro, 1977.

REVISTA ARQUITETURA E URBANISMO, Ano I, n. 3. Rio de Janeiro: I.A.B., 1936. REVISTA DE ARQUITETURA, n. 53. Rio de Janeiro, 1941.

RICOEUR, Paul. A memória, a história e o esquecimento. Campinas: Unicamp, 2008. . Tempo e narrativa: a intriga e a narrativa. São Paulo: Martins Fontes, 2010. v. 1.

SANTOS, Milton. A natureza do espaço: técnica e tempo, razão e emoção. São Paulo: Hucitec, 1999. 
SEVCENKO, Nicolau. Orfeu extático na metrópole: São Paulo, sociedade e cultura nos frementes anos 20. Sáo Paulo: Companhia das Letras, 1992.

\section{Fontes orais}

MORGADO, Renato Eloy. Entrevista de pesquisa realizada por Gianne Maria Montedônio Chagastelles em 28 de outubro de 2011 para tese de Doutorado em História Social do PPGHIS/IH-UFRJ. Apoiado pelo CNPq.

RESENDE, Osório Guimarães. Entrevista de pesquisa realizada por Gianne Maria Montedônio Chagastelles em 15 de outubro de 2011 para tese de Doutorado em História Social do PPGHIS/IH-UFRJ. Apoiado pelo CNPq.

WRIGHT, Luz Helena de Peyon. Entrevista de pesquisa realizada por Gianne Maria Montedônio Chagastelles em 17 de setembro de 2011 para tese de Doutorado em História Social do PPGHIS/IH-UFRJ. Apoiado pelo CNPq.

Resumo: Este estudo aponta para a transformação da paisagem da Avenida Beira Mar do Rio de Janeiro entre 1928 e 1950 . Investigo o processo de verticalização da região através das representações dos discursos dos usuários que assistiram às transformaçóes da cidade. Pretendo discutir as novas formas de moradia e controle do espaço natural e urbano decorrentes da instauração da arquitetura vertical. Mediante seleção e interpretação das representaçôes sobre a verticalização da paisagem dessa região, é possível reconhecer a cidade em seus múltiplos e dinâmicos significados históricos.

Palavras-chave: Rio de Janeiro, verticalização, paisagem.

\section{New skyline Beira Mar Avenue of Rio de Janeiro (1928-1950)}

Abstract: This study points to the transformation of the Beira Mar Avenue landscape in Rio de Janeiro between 1928 and 1950. I research the verticalization process in the region through the representations of the users, which assisted the city transformation. I pretend to discuss the new forms of housing and landscape and urban space control resulting from the introduction of vertical architecture. Through the selection and interpretation of these representations on the vertical landscape of Beira Mar Avenue it's possible to recognize the city in its multiple and dynamic historical meanings.

Key words: Rio de Janeiro, verticalization, landscape. 